\title{
Sulphydryl sensitivity of syphilitic antibodies and temperature dependence in complement fixation
}

\author{
M. SURJÁN, G. FỦST, AND I. BALOGH \\ From the Department of Serology, National Institute of Public Health, and Department I of Venereology, \\ Éva Kállai Hospital, Budapest, Hungary
}

Antibodies from syphilitic sera have been studied by ultracentrifugation (Davis, Moore, Kabat, and Harris, 1945; Aho, 1967), paper electrophoresis (Laurell, 1955), immunoelectrophoresis (Nørredam and Clausen, 1963), gel diffusion (Laurell, Oxelius, and Rorsman, 1968), or by DEAE cellulose column chromatography (Laurell and Malmquist, 1961), and gel filtration on Sephadex G-200 (Julian, Logan and Norins, 1969). The immunoglobulin classes in sera of patients with late syphilis have been studied using monospecific fluorescent antisera (Logan, Norins, Atwood, and Miller, 1969). Immunoglobulin sequence has also been studied. Different results were obtained, however, and because these methods are time-consuming only a few sera were examined.

It is generally accepted that the two most important classes of immunoglobulins differ in sedimentation characteristics as well as in their sensitivity to disulphide bond-reducing agents. Immunoglobulins of one class have sedimentation rates of $7 \mathrm{~S}$ and the second class of immunoglobulins have sedimentation rates of 19S. The latter are more sensitive to disulphide bond-reducing compounds, dissociating into smaller subunits and losing the capacity to combine with antigen after such treatment. The same procedure is ineffective with antibodies of the 7S class and the two classes can therefore be easily differentiated by 2 -mercaptoethanol treatment.

We have made a study of the sulphydryl sensitivity of syphilitic antibodies, and have also investigated the temperature dependence of 2-mercaptoethanol treated and untreated sera in complement fixation, to determine whether they fix complement more efficiently at $4^{\circ} \mathrm{C}$. or at $37^{\circ} \mathrm{C}$. Cunniff and Stollar (1968) established with several antigen-antibody systems the temperature dependence of complement-fixing capacity. They found that $7 \mathrm{~S}$ antibodies reacted much more efficiently at $37^{\circ} \mathrm{C}$. than at $4^{\circ} \mathrm{C}$. and that $19 \mathrm{~S}$ antibodies fix complement better at $37^{\circ} \mathrm{C}$. We have tried to discover how far the observations of Cunniff

Received for publication May 19, 1970 and Stollar (1968) could be applied to syphilitic sera, and hence to decide whether complement fixation of syphilitic sera with warm fixation could be applied in daily routine work because the procedure takes much less time.

\section{Material and methods \\ SERA}

Specimens sent to our Institute for serological tests for syphilis were investigated by the VDRL and complementfixation tests. Samples which fixed complement at a dilution of $1: 4$ or more were selected and stored at $-20^{\circ} \mathrm{C}$. until used. The 79 reactive sera studied by 2 -mercaptoethanol treatment could be divided into three groups according to the available clinical data: eight sera originated from cases of primary syphilis, 37 from cases of secondary syphilis, and 34 from cases of latent or late syphilis. Among a further 184 reactive sera examined simultaneously in cold and in warm fixation, 101 were from patients with primary or secondary syphilis and 83 from patients with late syphilis.

\section{ANTIGEN}

A commercial product of Kolmer cardiolipin antigen was used. It was controlled by the 50 per cent. haemolysis method in our department (Surján and Füst, 1968a)

\section{2-mercaptoethanol (ME) treatment}

Two different buffer solutions for diluting sera were made up:

(1) Phosphate buffered saline, $\mathrm{pH} 7 \cdot 2$, alone; $0.2 \mathrm{M}$ 2-ME in phosphate saline.

(2) Serum dilutions of $1: 2$ with and without $2-M E$ were allowed to set at room temperature for $4 \mathrm{hrs}$. The $2-\mathrm{ME}$ was removed by extensive dialysis against the same buffered saline.

\section{SERUM FRACTIONATION}

Some representative serum samples were fractionated on Sephadex G-200 columns. Sephadex fraction I contained 19S antibodies and fraction II contained 7S antibodies. The fractions were not anticomplementary.

QUANTITATIVE COMPLEMENT-FIXATION TESTS

These were performed with a microtechnique using Takátsy's microtitrator (Takátsy, 1955). We had previously compared this micromethod and the standard 
Kolmer technique on 1800 sera. The titres of 195 reactive sera obtained by parallel investigation with these two methods were estimated to $\log _{10}$-titres and results were mathematically analysed with Student's ' $t$ ' test. The difference of the mean of $\log _{10}$-titres was not significant $(P>0 \cdot 3)$ (Surján and Füst, 1968b).

The test itself was carried out by adding a calibrated drop of buffered saline $(0.025 \mathrm{ml}$.) in the holes of the plastic plates; titrations were started from the original dilutions of $1: 4$ of serum, with the wire loop of the microtitrator measuring $0.025 \mathrm{ml}$. serum dilutions into every hole. Antigen was diluted 1:75 and mixed with the same volume of complement dilution. From the antigencomplement mixture $0.025 \mathrm{ml}$. was dropped into the wells of the microtitrator and shaken vigorously. Reaction mixtures were incubated either at $4^{\circ} \mathrm{C}$. for $18 \mathrm{hrs}$. or at $37^{\circ} \mathrm{C}$. for $1 \mathrm{hr}$. before the addition of sensitized erythrocytes. It is to be noted that the amount of complement was varied for practical reasons so that four units of complement were employed in cold fixation and 1.5 units in warm fixation; this correction was necessary to diminish the difference between the warm and cold fixation. In both procedures $0.025 \mathrm{ml}$. of sensitized sheep erythrocyte suspension was dropped into every hole and the plates were incubated for $60 \mathrm{~min}$. at $37^{\circ} \mathrm{C}$. Thereafter the plates were put into a refrigerator for $15 \mathrm{~min}$.

\section{READING OF THE REACTION}

The area of the pattern formed by the undissolved erythrocytes in the last dilution indicated the titres of the sera, which ranged between 16 and 1024 .

\section{STATISTICAL ANALYSIS}

The titres of the complement-fixation tests were estimated to $\log _{10}$-titres according to the method of Kärber (1931). The results were evaluated by Student's ' $t$ ' test.

\section{Results}

The complement fixation of 79 syphilitic sera and of their ME-treated samples was performed at $37^{\circ} \mathrm{C}$. and at $4^{\circ} \mathrm{C}$. simultaneously. The results are presented in the Table. ME treatment resulted in a highly significant $(P<0.001)$ titre decrease in both cold and warm fixation. Although we employed different amounts of complement so as to diminish differences between cold and warm fixation, the titre decrease was more marked in warm fixation than in cold, and the difference was highly significant $(P<0.01)$.

According to sulphydryl sensitivity and temperature dependence in complement fixation, the 79 reactive sera could be divided into five groups (Fig. 1).

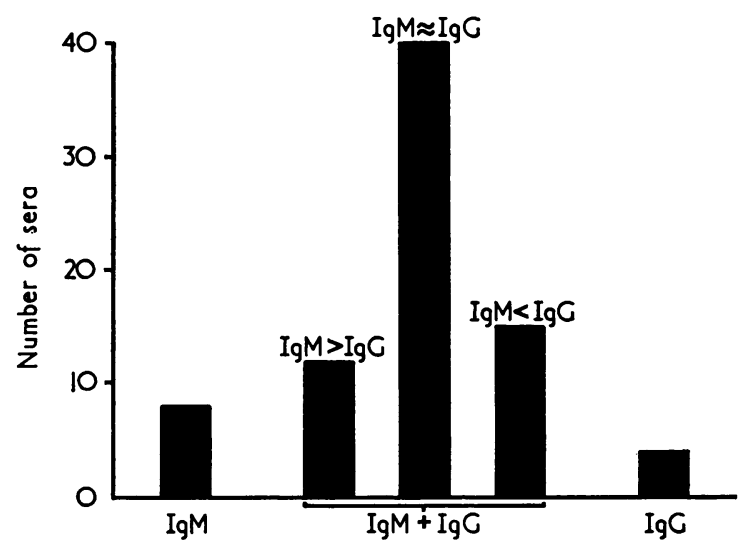

FIG. I Immunoglobulin classes in 79 sera

GROUP 1. SERA CONTAINING EXCLUSIVELY $19 S$

10 per cent. of the sera contained exclusively antibodies probably of IgM class. ME treatment effected a decrease to zero in the titre of the sera; the original titre was higher in warm fixation.

GROUP 2. SERA CONTAINING PREDOMINANTLY IgM

Before treatment the titres of the sera were higher in warm fixation; after treatment a significant fall in titre could be observed. The fact that some titres remained unaltered after $\mathrm{ME}$ treatment could be ascribed to the presence of antibodies of IgG class, which is why this residual titre is higher in cold fixation. 15 per cent. of sera belong to this category.

GROUP 3. SERA WITH IgM AND IgG ANTIBODIES IN APPROXIMATELY EQUAL PROPORTIONS

Half the sera (51 per cent.) were in this group. ME treat-

TABLE Effect of 2-mercaptoethanol treatment on titre of complement-fixation reaction (comparison of cold and warm fixation)

\begin{tabular}{|c|c|c|c|c|c|c|c|}
\hline \multirow[t]{3}{*}{ Sera } & \multicolumn{6}{|l|}{ Fixation } & \\
\hline & \multicolumn{3}{|l|}{ Cold } & \multicolumn{3}{|l|}{ Warm } & \\
\hline & No. of sera & Amount of $\log _{10^{-}}$-titres & Mean of $\log _{10^{-}}$-titres & No. of sera & Amount of $\log _{10}$-titres & Mean of $\log _{10}$-titres & \\
\hline Untreated & 79 & $76 \cdot 035$ & 0.965 & 79 & $74 \cdot 716$ & 0.946 & \\
\hline Treated & 79 & $50 \cdot 980$ & 0.645 & 79 & $38 \cdot 533$ & 0.488 & \\
\hline Decrease & - & $25 \cdot 055$ & $0.320=A^{\star \star \star}$ & - & $36 \cdot 183$ & $0.458=B^{\star \star \star}$ & $\begin{array}{l}\mathrm{B}-\mathrm{A}= \\
0 \cdot 138^{\star \star}\end{array}$ \\
\hline
\end{tabular}

$\star \star=$ highly significant difference $(P<0.01)$

$\star \star \star=$ highly significant difference $(P<0.001)$ 
ment caused only a slight decrease in titre, and sera showed the same reactivity in cold and warm fixation.

GROUP 4. IgG PREDOMINANT IN 10 PER CENT.

Reactivity was higher in cold fixation before as well as after treatment; ME treatment caused only a slight change.

\section{GROUP 5. SERA CONTAINING EXCLUSIVELY IgG}

These formed 5 per cent. of the total. They were resistant to $\mathrm{ME}$, and the reactivity was more effective in cold fixation.

Thus the majority of sera from syphilitic patients with primary, secondary, and late syphilis contained antibodies of both IgM and IgG classes. 10 per cent. of the sera contained exclusively IgM and only 5 per cent. exclusively IgG. This confirmed the supposition that complement fixation in syphilitic sera is temperature dependent; furthermore our findings that IgM occurs in or is predominant in the majority of the sera was also confirmed.

The question arises whether it is right to perform syphilitic complement-fixation tests at $4^{\circ} \mathrm{C}$. for $18 \mathrm{hrs}$., if $19 \mathrm{~S}$ antibodies are present in the majority of syphilitic sera examined. To resolve this question the complement fixation of 184 routine sera was carried out in parallel by cold and warm fixation. 84 per cent. of the 184 sera gave the same results in cold and warm fixation, 10 per cent. were more sensitive in cold, and 6 per cent. in warm (Fig. 2).
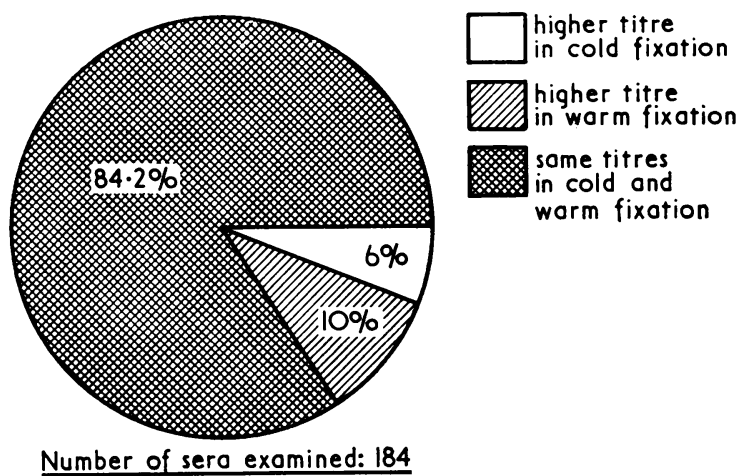

FIG. 2 Percentage results of cold and warm fixation in 184 sera

In Fig. 2 the titres are estimated to $\log _{10}$ values. From the diagnostic point of view it is more important that out of the 184 sera four reacted only in cold fixation, and six only in warm fixation. This means that warm fixation can be safely used in our routine tests. It may also be stated that the use of the time-consuming cold fixation is not justified, because the $1 \mathrm{hr}$. incubation at $37 \mathrm{C}$. does not result in lower values. The practical significance of these findings is obvious.

The pattern of Sephadex fractions after ME treatment and their temperature dependence in complement fixation was the same as that of whole sera.

\section{Discussion}

The ME treatment of 79 syphilitic sera offered an opportunity to study the two most important immunoglobulin classes.

Cunniff and Stollar (1968) demonstrated in several antigen-antibody systems that not only the type of antigen but also the temperature has a marked influence on complement-fixation reactivity. $7 \mathrm{~S}$ antibodies reacted more strongly at $4 \mathrm{C}$., while $19 \mathrm{~S}$ antibodies reacted better at $37^{\circ} \mathrm{C}$. It is of special interest that these authors obtained slightly different patterns just with syphilitic sera. Examining a pooled serum of high titre, they found that the whole serum reacted more strongly at $4 \mathrm{C}$. which could be ascribed to its higher IgG content. But the IgM fraction of this single serum did not react more effectively at $37^{\circ} \mathrm{C}$. Our data demonstrate that the findings of Cunniff and Stollar (1968) observed in several antigenantibody systems may also be valid in respect of the complement fixation of syphilitic sera.

Immunoglobulin sequence is one of the several unsolved problems concerning immunity against syphilis. It has been demonstrated in experimental syphilis that rabbit sera in the early stage of the disease contain anticardiolipin antibody of IgM type, while at later stages IgM and IgG types occur together. In late syphilitic rabbit sera only the reactivity of IgG antibodies could be detected (Julian and others, 1969). In human sera this sequence could not be demonstrated (Aho, 1967; Laurell and Malmquist, 1961). Our examinations cannot resolve this problem, but it must be stressed that in some sera we found exclusively IgM antibodies, and in others exclusively IgG antibodies among early as well as late syphilitic sera (Tringali, 1965).

Examination of the 184 routine sera also revealed that 73 per cent. of the sera, reacting more strongly in warm fixation (supposedly IgM dominance) originated from patients with early syphilis. On the other hand, 67 per cent. of the sera reacting more strongly in cold fixation were from patients with late syphilis. Thus IgM seems to prevail in recent infections, and IgG in the later stages, but the regular IgM-IgG sequence observed in other systems could not be detected in our specimens. Other reports in the literature also indicate that a regular IgMIgG sequence cannot be regarded as a general phenomenon (Freeman and Stavitsky, 1965).

\section{Summary}

79 sera reactive in serological tests for syphilis were treated with 2-mercaptoethanol. According to the sulphydryl sensitivity the sera could be divided into five groups:

(1) 10 per cent. contained exclusively antibodies of IgM class.

(2) 15 per cent. showed IgM predominance.

(3) 51 per cent. contained IgM and IgG antibodies in approximately equal proportions.

(4) 19 per cent. showed IgG predominance.

(5) 5 per cent. contained IgG alone. 
The complement-fixation reactivity of antibodies of IgM class was more effective at $37^{\circ} \mathrm{C}$. Complement-fixation reaction of 184 syphilitic sera examined in parallel by cold and warm fixation demonstrated that time-consuming cold fixation is not justified, because the $1-\mathrm{hr}$ incubation at $37^{\circ} \mathrm{C}$. did not result in lower titres.

\section{References}

AHo, K. (1967) Brit. f. vener. Dis., 43, 259

CUNNIFF, R. V., and StollaR, B. D. (1968) f. Immunol., 100,7

Davis, B. D., MOore, D. H., Kabat, E., and Harris, A. (1945) Ibid., 50, 1

Freeman, M. J., and Stavitsky, A. B. (1965) Ibid., 95, 981

Julian, A. J., Logan, L. C., and Norins, L. C. (1969) Ibid., 102, 1250

KÄRBER, G. (1931) Naunyn-Schmiedeberg's Arch. exp. Path. Pharm., 162, 480 (cited by J. H. Gaddum, Spec. Rep. Ser. med. Res. Coun., Lond., 1933, No. 183)

LAURELL, A.-B. (1955) Acta path. microbiol. scand., Suppl. 103

- - and Malmouist, J. (1961) Ibid., 51, 187

- Oxelius, V. A., and Rorsman, H. (1968) Acta derm.-venereol. (Stockh.), 48, 268

LogaN, L. C., Norins, L. C., ATwOod, W. G., and MILLER, J. L. (1969) f. invest. Derm., 53, 300

NøRREDAM, K., and ClAUSEN, J. (1963) Acta derm.-venereol. (Stockh)., 43, 413

SurJáN, M., and Füst, G. (1968a) Z. Immunforsch., 136, 303
TAKÁtsy, G. (1955) Acta microbiol. Acad. Sci. hung., 3, 191

Tringali, G. (1965) Riv. Ist. sieroter. ital., 40, 243

La sensibilité sulfhydrilique des anticorps syphilitiques et l'influence de la température dans la fixation du complément

\section{SOMMAIRE}

79 sérums sérologiquement réactifs pour la syphilis furent traités par le 2-mercatoethanol. Selon la sensibilité sulfhydrilique, les sérums peuvent être divisés en cinq groupes:

(1) 10 pour cent contenaient exclusivement des anticorps du groupe IgM

(2) 15 pour cent montraient une prédominance $\operatorname{IgM}$

(3) 51 pour cent contenaient des anticorps IgM et IgG en proportion à peu près égale

(4) 19 pour cent montraient une prédominance IgG

(5) 5 pour cent contenaient seulement des anticorps du groupe IgG

En réaction de fixation du complément, la réactivité des anticorps du groupe IgM a été plus grande à $37^{\circ} \mathrm{C}$. L'étude de la réaction de fixation du complément de 184 sérums syphilitiques, examinés en parallèle après fixation à froid et à chaud, a montré que la fixation à froid, qui prend du temps, n'est pas justifiée car l'incubation pendant 1 heure à $37^{\circ} \mathrm{C}$. ne donne pas des titres inférieurs. 